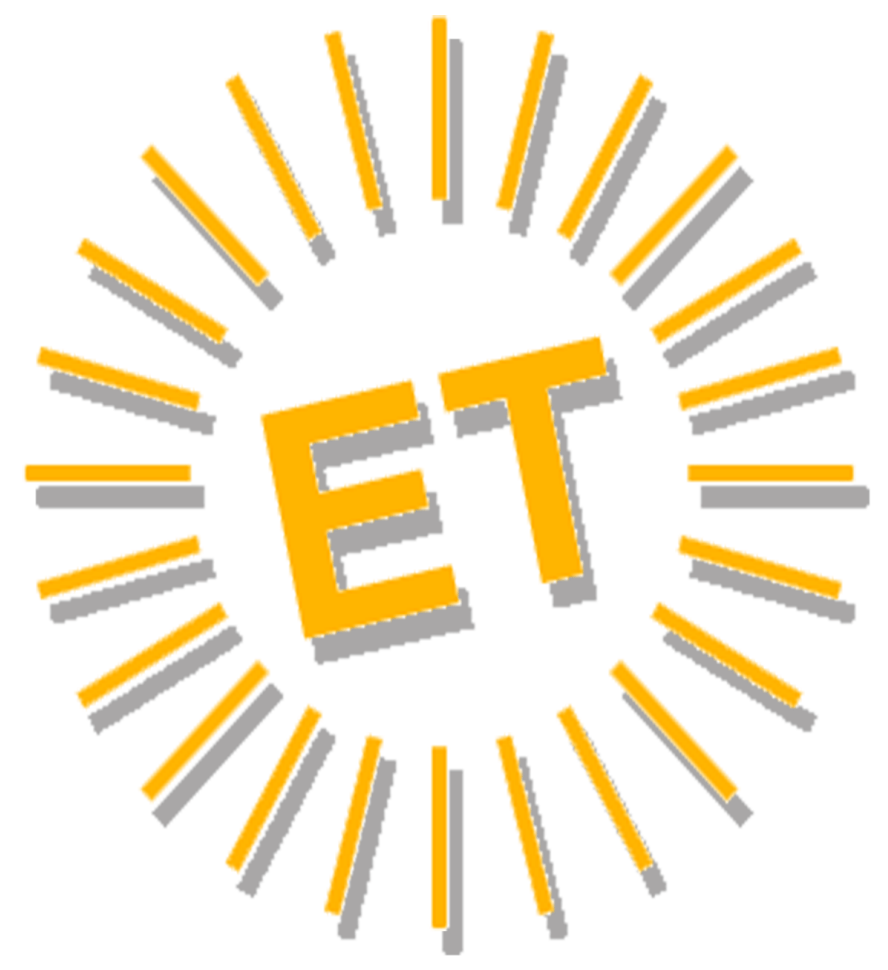




\section{Editorial Team}

Editor in Chief

Alfonso Vargas-Sánchez, University of Huelva, Spain

\section{Associate Editor}

T.C. Huan, National Chiayi University, Taiwan

\section{Books Review Editor}

Brendan Paddison, York St. John University, United Kingdom

\section{Secretariat}

Elena García de Soto, University of Huelva, Spain

Cinta Borrero-Domínguez, University of Huelva, Spain

\section{Style reviewer and text editor}

Anestis Fotiadis, I-SHOU University, Taiwan, Province of China

\section{Editorial Board}

José Manuel Alcaraz, Murdoch University, Australia Mario Castellanos-Verdugo, University of Seville, Spain José Antonio Fraiz-Brea, University of Vigo, Spain José Manuel Hernández-Mogollón, University of Extremadura, Spain

Shaul Krakover, Ben Gurion University, Israel Jean Pierre Levy-Mangin, University of Quebec, Canada Tomás López-Guzmán, University of Córdoba, Spain Yasuo Ohe, Chiba University, Japón Mirko Perano, University of Salerno, Italy María de los Ángeles Plaza-Mejía, University of Huelva, Spain Nuria Porras-Bueno, University of Huelva, Spain João Albino Silva, Algarve University, Portugal

\section{Advisory Board (Spanish Members)}

César Camisón-Zornoza, Uniersity of Valencia, Spain Enrique Claver-Cortés, University of Alicante, Spain María Teresa Fernández-Alles, University of Cádiz, Spain José Luis Galán-González, University of Seville, Spain Félix Grande-Torraleja, University of Jaén, España Antonio Leal-Millán, University of Seville, Spain Inmaculada Martín-Rojo, University of Málaga, Spain Antonio Manuel Martínez-López, University of Huelva, Spain Francisco José Martínez-López, University of Huelva, Rector, Spain

Pablo A. Muñoz-Gallego, University of Salamanca, Spain
Francisco Riquel-Ligero, University of Huelva, Spain José Miguel Rodríguez-Antón, Autonomous University of Madrid, Spain

Sandra Sanchez-Cañizares, University of Cordoba, Spain Josep Francesc Valls-Giménez, ESADE, Spain

\section{Advisory Board (Other European Members)}

Paulo Aguas, University of Algarve, Portugal Gustavo Barresi, University of Messina, Italy Carlos Costa, Aveiro University, Portugal Salvatore Esposito de Falco, University of Rome "La Sapienza", Italy

Sheila Flanagan, Dublín Institute of Technology, Ireland Tania Gorcheva, Tsenov Academy of Economics, Bulgaria Tadeja Jere-Lazanski, University of Primorska, Slovenia Metin Kozak, Mugla University, Turkey Álvaro Matias, Lusiada University, Portugal Alfonso Morvillo, National Research Council, Italy Alexandru Nedelea, Stafan cel Mare University of Suceava, Romania

Claudio Nigro, University of Foggia, Italy

Angelo Presenza, University "G. D'Annunzio" of ChietiPescara, Italy

Kanes Rajah, Royal Agricultural University, United Kingdom

\section{Advisory Board (Members from the rest of the world)}

John Allee, American University of Sharjah, United Arab Emirates

Nestor Pedro Braidot, National University of La Plata, Argentina

Roberto Elias Canese, Columbia University, Rector, Paraguay

Luca Casali, Queensland University of Technology, Australia Nimit Chowdhary, Indian Institute of Tourism and Travel Management, India

Steven Chung-chi Wu, National Pingtung University of Science and Technology, Taiwán

Dianne Dredge, Southern Cross University, Australia Daniel Fesenmaier, Temple University, United States

Babu George, Alaska Pacific University, United States Dogan Gursoy, Washington State University, United States Jafar Jafari, University of Wisconsin-Stout, United States Sanggun Lee, Pai Chai University, Korea Republic of Albert Yeh Shangpao, I-SHOU University, Taiwán Pauline Sheldon, University of Hawaii, United States Germán A. Sierra-Anaya, University of Cartagena de Indias, Rector, Colombia Xiaohua Yang, University of San Francisco, United States 


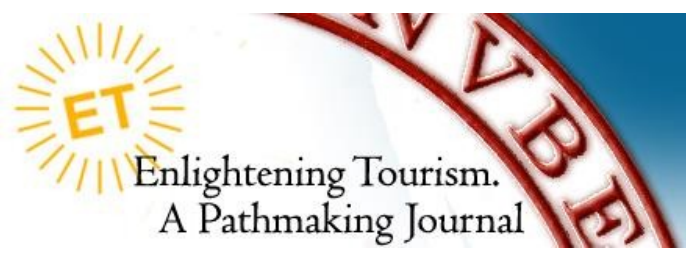

\title{
THE ROLE OF PERSONAL BRAND ON CONSUMER BEHAVIOUR IN TOURISM CONTEXTS: THE CASE OF MADEIRA
}

\author{
Bruno Sousa \\ Polytechnic Institute of Cávado and Ave (IPCA), Portugal \\ bsousa@ipca.pt \\ Sónia Rodrigues \\ Polytechnic Institute of Cávado and Ave (IPCA), Portugal \\ sonia.rodriques005@gmail.com
}

\begin{abstract}
In a world that undeniably competes for investment, visitors and residents, the adoption of approaches derived from the marketing has become a reality in the search for sustainability. It is a fact that a city marketing and brand management policy is able to promote and transform an image, boost economic activity and enhance all aspects of the city that present competitive advantage over other territories, so this is why associate marketing with cities makes sense. This study aims a better understanding of the brand image and their relationship with behavioral intentions, especially through the perceptions that tourists have toward the destinations (e.g. Madeira island), and how this may influence their attitudes. The objective of this study is to understand the impact of the personal brand on the image of a tourist destination, using as a case study the Madeira destination. The data for this study were collected by a self-administered questionnaire method in Madeira International Airport (Funchal, Portugal in 2017, with 147 valid responses). It was possible to understand the perception of visitors and assess the experience of visitors and the theoretical and practical contributions to local development and tourism marketing. Under an interdisciplinary perspective, this research brings together inputs from marketing, tourism and local economics. A theoretical model is developed specifying antecedents of satisfaction and loyalty in specific tourism contexts. Implications for future research are also presented.
\end{abstract}


KEYWORDS

Brand Management; CR7; Tourism Marketing; Madeira Island, Personal Branding.

ECONLIT KEYS

$Z 33$

\section{INTRODUCTION}

Tourism activities are amongst the most relevant drivers of economic development and growth in various economies (Sousa \& Simões, 2010) compromising sustainable development (Holladay et al., 2018). The tourism in Portugal has become a sector in constant growth and with a high refection on the region's economy. In 2016 the growth was $11.5 \%$ over the previous year, which resulted in an increase of about 40000 jobs. Madeira, presents among the regions with the highest tourist demand at national level, with the tourism industry its main economic activity. This market offers a range of natural, cultural and patrimonial tourism resources, which together with the security and the mild climate that is felt during all the months of the year, makes this region a mature destination already consolidated. However, in an increasingly globalized world, and in the face of global competition, it is necessary to use strategies of promotion and communication, a tool that aims to reach the mind of the consumer (García de Soto Camacho \& Álvarez Torrescusa, 2018). Very often the brand of tourist destinations uses the image for the promotion of destinations using the existing attributes in the same, whether tangible or intangible attributes such as security, hospitality, climate, among others whose ultimate goal is to satisfy the needs.

The promotion of the image of a certain destination aims to capture the attention of potential tourist consumers whose purpose is the sale of their products and services (Ferreira, Sousa \& Gonçalves, 2018). The entities responsible for the promotion and dissemination of the Madeira destination use various tourism promotion campaigns associated with regional events such as the flower festival, fireworks in the new year, or other natural resources, which are associated to the image Madeira. Among the various forms of promotion can be found marketing campaigns to associate certain figures to the Madeira destination, such as promoting the destination through the brand Cristiano Ronaldo. He was born in 
Madeira an illustrious figure of the world of football with recognition international level. With a brilliant career, and several appointments in the football world, Cristiano Ronaldo became an emblematic symbol that associates your brand not only to the world of football, as well as the various sectors among which stands out the partnership with the hotels in the Pestana group on the island of Madeira in Lisbon, and in the very near future in New York, Madrid in Morocco in the city of Marrakesh, scheduled to open in 2019. On this way and to try to understand how a personal brand can influence the image of a destination, we propose to carry out a study on the subject in order to test and prove or not the importance of the personal brand (i.e. CR7) in the image of a tourist destination, in this case Madeira. To the endeavor an interdisciplinary perspective is taken bringing together inputs from marketing, tourism and local economics. A research model is developed and implications for future research suggested.

\section{PERSONAL BRANDING IN TOURISM CONTEXTS}

A brand is a distinguishing name and/or symbol (such as logo, trademark, or package design) intended to identify the products or services of either one seller or a group of sellers, and to differentiate those products or services from those of competitors (Ghodeswar, 2008). A brand provides the basis upon which consumers can identify and bond with a product or service or a group of products or services. Brands serve as a guiding map to purchasing behaviour and, when managed correctly, often result in significant value for their holders (Anholt, 2005). Assets of the company, it is not surprising that step by step and has gained the attention of marketers, also because beyond the financial value of brands there is no less important social value. Brands are not just a sign. Brands are not just elements that position products and companies. For many years, brands have been regarded as links between products/companies and their customers (Brito, 2010). Although social media offer new opportunities, branding is by no means a new phenomenon. Early definitions of branding (Lair et al. 2005; Murphy 1987) focus on the way producers try to sell products as unique and distinctive. Since the 1990s, the concept is also used to describe the marketing of people. Tom Peters 
(1997) popularized the term "personal branding" in the article "The Brand Called You" (Lair et al. 2005; Labreque et al. 2011; Brems, Temmerman, Graham \& Broersma, 2017).A brand is an identifier of a product that distinguishes from others. Apart from being an aid in the purchase decision process, responsible who produces or sells the product (improving confidence) (Sousa \& Vasconcelos, 2018). There are a number of brands on the market that are designed to meet the varied needs of consumers, but consumers are willing to pay high brands for brands with high economic value and social status rather than low prices for cheaper brands, brands with no social impact, or brand equity brands (Kotler \& Gertner, 2004). The brand always reveals itself as a promise of something to the consumer (Moilanen \& Rainisto, 2009). According to Johnson (2017), personal branding is the process by which an individual actively tries to manage others' impressions of their skills, abilities and experiences. Self-awareness and understanding one's strengths and weaknesses in order to effectively present the self is essential to building a personal brand. Personal branding is the practice of marketing oneself to society (Brooks \& Anumudu, 2016; Gehl, 2011; Lair, Sullivan \& Cheney, 2005; Khedher, 2014; Khedher, 2014; Kleppinger \& Cain, 2015; Peters, 1997; Rampersad, 2001; Shepherd, 2005). An individual personal brand is a reflection of his or her skills, abilities and lifestyle (Gehl, 2011; Hearn, 2008; Peters, 1997). Developing a personal brand is an ongoing process that involves interactions with others in face-to-face communication and online (Hearn, 2008, Khedher, 2015; Peters, 1997; Vitberg, 2009).

In this contexts, the city marketing, or marketing of cities, is one of the areas of marketing where there has been a higher growth and more relevant for the development and growth of cities. While the need to differentiate and assert their individuality in various aspects, whether economic forum, social or political, is already a concern that dates back almost to the beginning of the governments and the cities of marketing have been used since the nineteenth century Kavaratzis (2004) was only in recent decades that cities began to employ more intensively, techniques derived from the marketing, since it was at this time that the competition for investment, tourism revenues and concern in attracting new residents intensified and they became an object of study in how cities should be managed. 
The topic of residents' attitudes toward tourism development has been analyzed by many authors (e.g. Vargas-Sánchez, Plaza-Mejia, M. \& Porras-Bueno, 2009; Vargas-Sánchez, Porras-Bueno \& Plaza-Mejía, 2011; Vargas-Sánchez, PorrasBueno \& Plaza-Mejía, 2014), but there have been few studies that have included the impacts resulting from tourism perceived by residents of a particular region in a very early stage of tourism development, where, consequently, this industry is not yet economically important, the relationship between the impacts of tourism perceived by residents and their degree of satisfaction with their community (Vargas-Sánchez, Plaza-Mejia, M. \& Porras-Bueno, 2009). For instance, and according to Vargas-Sánchez et al. (2011), research conducted in this field is considered important because understanding the reasons why the residents do or do not support the tourism industry and its growth will help to establish models for such developments that minimize the negative social impacts and maximize the support for these initiatives. The growing business opportunity in the services sector, where cities are incorporated, and reinforces the similarities that this sector has with the business activity and the way some tools adapted to this new reality can be fundamental knowledge of how will the cities affected by any changes (Sousa \& Ribeiro, 2018). Even with regard to this issue, the concepts of social marketing (Kotler \& Zaltman, 1971), the nonprofit marketing (Kotler \& Levy, 1969) and the notion that the image to which individuals associate a product with poorly contoured outlined, as the cities seen as a product are, they were also major drivers, since it showed that the marketing did not enjoy just to make a profit, but also creating initiatives that define the main objective of the common good (Kotler, Haider \& Rein, 1993).

In the context of tourism, there are differences, similarities or interrelationship between the brand and image of a destination (Tasci \& Kozac, 2006). A brand is linked to the image of a destination, however the brand of a destination is more durable than the image of a destination (Kozak, 2003). Blain et al. (2005) suggests that the brand of a destination can be defined as a set of marketing activities that support the creation of a name, symbol, logo, word or other graphic elements that identify and differentiate the destination; which carry the promise of a memorable travel experience and only associated with this destination; and that consolidate 
and reinforce the gathering of pleasant memories of the destination experience, in order to create an image that influences the decision to visit the destination.

Places have had, for quite some time, the need to differentiate from each other in order to claim their individuality and distinctive features in achieving economic, political or socio-psychological objectives. Ashworth and Voogd (1994) state that the beginning of place promotion, by creating a favorable image of this to potential customers, investors or residents, appears in the eighth century when Leif Ericson started to look for new settlers to occupy their land "green" newly discovered. Although this is not yet marketing in its fullness, since promotion is just one of its tools, one begins now to show a concern to manage territories. Kavaratzis and Ashworth (2008) argue that the practice of Marketing developed through certain phases over time, grouping them into three categories, that do not follow a specific line of time, or a distinctive geographical area. In this context, you reach a targeted place marketing, with specific target audiences, and place branding is consolidated, emerging a concern with the image that the place transmits, rather than simple advertising (Sousa \& Vasconcelos, 2018). The image in a tourism context constitutes an important part of the brand because it contributes not only to its formation, but also to its success in the market, although considering the fact that the brand is much more than an image. According to these authors the brand involves two types of image, the projected image and the image perceived by the consumer. In this way the brand of a destination and the meanings attributed to it is projected and disseminated through an image by the various institutional entities. However, this image can be transformed because it may suffer changes due to several factors such as the media, among others, thus losing the meanings that were attributed to it, giving current or potential visitors a projected image of the destination other than that intended, which may result in differences between the projected image and the perceived image of a tourism destination in the consumer's mind (Tasci \& Kozac, 2006).

According to Zarkada (2012) a personal brand is a marketing concept that is related to the strategies adopted by a particular individual in the promotion of their skills and abilities, these being the same strategies used in the marketing of products. According to Khedher, (2013) every individual can be considered brand, 
since everyone has their own identity regardless of age, sex or profession. For Khedher (2013), personal branding is the name adopted for the construction of the personal brand, this is characterized by the establishment of a unique identity, which follows communication with a certain target audience. Personal branding is also characterized by the continuous evaluation of the impact of your image and reputation based on the satisfaction of previously defined professional and personal goals. According to Montoya and Vandehey, (2008) throughout the construction of his personal brand, the individual can specialize in his / her area of interest thus becoming a reference in it. The process is based on the creation of the Brand Identity where the internal characteristics inherent to the individual are identified, such as attributes, beliefs, values, or experiences. The development of Brand Positioning is related to the promotion of the individual, its differentiation from the competition, and Brand Image Evaluation where the individual can assess whether the brand's goals have been achieved, as well as their personal goals. Personal branding emerges as a solution-oriented effort (take control of one's own).

\section{BEHAVIOURAL INTENTIONS IN TOURISM CONTEXTS}

Consumer behavior comprises a set of directly related activities where the decision has influence in the other processes such as the obtaining and the consumption of the good or services, according to which there is a relation with the purchase process, its consumption and later rejection (Engle, Blackwell \& Miniard, 2000). Consumer behavior is characterized by the mental and emotional activities performed in the selection, purchase and use of products or services to satisfy their needs and desires (Richers, 1984).Tourism demand is influenced by several factors, among which social, economic and cultural factors, technological changes, the demographic structure of a country, the increase of free time; the motivations to travel; purchasing power; the excessive urban concentration that causes additional wear and tear, the originality, image, attractiveness and accessibility of a particular tourist destination.

Consumer satisfaction in the tourism industry is a factor whose importance has 
been widely recognized by several authors (e.g. Baker \& Crompton, 2000; Kim et al., 2013). This importance is due to the fact that satisfaction is a factor that will influence the tourist to revisit or not a certain tourist destination (Kozak \& Rimmington 2000). A destination can be seen as "a package of services and tourist facilities which, like any other consumer product, is composed of a number of multidimensional attributes" (Hu \& Ritchie 1993: 26). Oliver (1981) argues that customer satisfaction can be understood as the resulting psychological state when the emotion around unconfirmed expectations is associated with the consumer's previous feelings about the consumer experience. According to Kotler (2000), satisfaction can be understood as a feeling of pleasure that results from the comparison and performance of the product, in relation to the expectation created by the consumer. According to Baker and Crompton (2000) in the tourism sector, consumer satisfaction corresponds to their emotional state after their experience and can be influenced in a positive or negative way according to which their emotions can intervene or establish a link between behavior and satisfaction (Otto \& Ritchie, 1996). There are a numerous studies that aim to determine how consumer satisfaction and loyalty can influence their behavior in the repurchase of a particular service or product (Ostrom \& lacobucci 1995). Although there is no consensus regarding the relationship (Cronin, Brady, \& Hult, 2000). In this paper, we present a comparison of the relationship between satisfaction and purchase intention.

There are many definitions regarding the concept of loyalty but there is no consensus as to its definition. According to Dick and Basu (1994), loyalty is related to individual attitudes and repeated buying behavior. Destination loyalty can be understood from the behavioral point of view when referring to the commitment to repeat the purchase although there are influences and marketing techniques that aim to change consumer buying behavior. According to Keller and Lehmman (2006), customer satisfaction increases the willingness to pay for the service or product while also increasing brand loyalty. In this way satisfaction appears as an anticipator of loyalty (Parasuraman et al., 1985).

Given the above, it was adopted a conceptual model developed by Bigné et al. (2001), which sets the relationship between different variables based on the set of 
postulated hypotheses to test in this context study. The authors aim with this model to understand the role of the image in post-purchase behaviour of tourists, thus providing several variables. However, this paper is intended to study the role of the image throughout the whole process of tourist buying behaviour, so it was added a sixth variable: purchase. The choice of these variables relates to all stages inherent to the tourist buying behaviour process. First, the tourist makes a request for information and evaluates alternatives, taking then a buying decision (purchase variable). During his stay the visitor lives the experience, which can offer him quality or not and, consequently, satisfaction or dissatisfaction (variable satisfaction). Taking into account the feelings and memories with which the tourist was left, it may have the intention of returning to visit the destination (variable return) and recommend it to family and friends (variable recommend). These variables appear to understand the role of this mechanism throughout.

\section{METHODHOLOGY AND RESEARCH MODEL}

The objectives of this paper deal, on the one hand, with the identification of the specific factors that are likely to adversely affect the competitiveness of tourism destinations in specific tourism marketing contexts and, on the other hand, assessing the importance given by the tourism demand to factors that potentially influence the competitiveness of these tourism destinations (i.e. Madeira).

The practical value of research in the field of leisure constraints has been well documented (e.g. Howard \& Crompton, 1984; Veal \& Cushman, 1996). McGuire and O'Leary (1992) stated that the area of leisure constraints is one with tremendous potential for linking research with practice. As Veal (2017) notes, there are a number of different ways to make a piece of research original, such as testing an existing theory in a different geographical area, or replicating an existing study using a different methodology.

This research also aims to assess to what extent the form of the questions could influence results, i.e., if the use of a quantitative methodology (closed-ended questions) influences the importance attributed to different factors or even reveals the existence of factors that are not usually taken into consideration. In the present study, 
we are dealing with a non-probabilistic sampling, since the probability of a certain element belonging to the sample is not equal to that of the other elements. The sample is formed respecting a certain type of convenience, on the part of those who form the sample or on the part of those who will participate (Maroco, 2007; Hair et al., 2009). The pre-tested questionnaire was initially developed in two languages: Portuguese and English. A total of three hundred questionnaires were distributed to the tourists. In order to measure and analyze the impact of the personal brand in the tourism context applied to the case Madeira, this study utilizes 28 items. Out of 300 questionnaires distributed, a total of 147 usable questionnaires were collected, yielding a 49\% response rate. Missing values, outliers, and distribution of all measured variables were examined to purify the data and reduce systematic errors.

The data for this study were collected by a self-administered questionnaire method in Madeira International Airport (Funchal, Portugal - January 2017, during four days). In 2017, Madeira Airport registered an annual total of 3.202 .527 passengers (an average of 8.774 per day). Our sample size (147 responses) represents a margin of error $6.77 \%$ with a $90 \%$ confidence level. The data obtained from the two openended questions were subjected to content analysis using the SPSS. For the closedended question, a Likert scale of five points was used from 1 "unimportant" to 5 "very important" to assess the importance of each item. In present research we chose to do a casual descriptive research in order to inventory facts, observe certain phenomena and identify variables in order to test hypotheses whose purpose is to establish cause-effect relationships between the various variables.

The study combines quantitative embroidery through a variety of exploratory surveys and a quantitative approach through the administration of questionnaires, with data collection performed only once, with a single sample. Subsequently, and in order to carry out an empirical study on the subject, methods were established in order to answer the initial questions elaborated. A theoretical model is developed specifying antecedents of satisfaction and loyalty in cross-border tourism regions. Implications for future research are also presented. Several studies investigated the significant associations between place attachment and other consumer-related variables (Sousa \& Vieira, 2018), including satisfaction and service quality (Hwang et al., 2005). According to Bigné and Andreu (2004), although researchers agree on the 
importance of the relationships between emotional and affective variables, tourist satisfaction and behavioural intentions, there are no conclusive findings on how these variables connect. In order to understand the importance of personal branding in tourism contexts, the central problem of our study, it was necessary to select a set of variables and hypotheses that were interrelated in order to reach the desired conclusions.

The five presented variables give rise to a set of six hypotheses that establish a relation between them, susceptible of being tested, originating a system that will answer the questions of investigation, after the collection of the empirical data. The study variables were measured using a 5-point Likert scale, using values ranging from $1=$ Totally Disagree to $5=$ Totally Agree, all of them composed of several items. Figure 1 shows the conceptual model of the present study:

Purchase: 1. Culture and Tradition; 2. Natural beauty and landscape; 3. Gastronomy and Wines; 4. Heritage Interest; 5. Sports and Recreation; 6. Affordable Price; 7. Hospitality and Security; 8. Notoriety oh the Brand CR7.

Destination image: 1.Nature and Walks 2. Beach; 3. Festivities (Flower festival, Carnival, Reveillon); 4. Food and Wine; 5. Business; 6. CR7 Brand

Personal branding: 1.The image CR7 influence the decision to purchase the destination Madeira; 2.The CR7 brand has a high impact on the region's image; 3.The museum CR7 is a relevant attribute in this destination; 4. The hotel Pestana ICR7 has an important value for those who visit this region; 5 . The Change of airport name to "Madeira-Cristiano Ronaldo Airport" will have a positive influence on the decision to return

Satisfaction: 1. This is one of the best regions that is could have visited; 2. I am pleased with my decision to visit Madeira; 3. My choice in visiting Madeira was prudent; 4. I really had a lot f fun on my visit; 5 . I am sure it was the best decision to visit Madeira.

Destination loyalty: 1 Probability to say positive things about the region to other people; 2 . Probability to suggest the region to friends and family as a destination to visit; 3. Probability to encourage friends and family to visit the region; 4.Probalility to consider Madeira as a choice to visit in the future. 


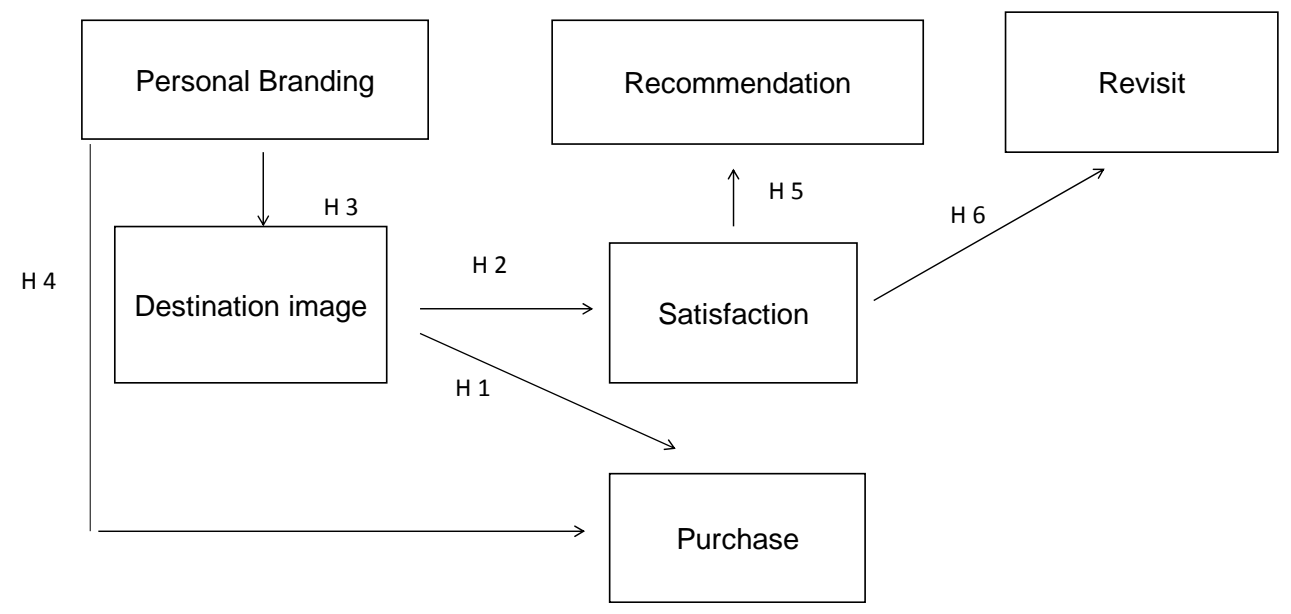

Figure 1: The impact of the personal brand on consumer decision on tourism - the case of Madeira

- Hypothesis 1: The more positive the image of the target, the greater the likelihood of buying from the consumer. Regarding the correlation between the target image variable and the satisfaction variable, it obtained a lower result when compared to the previous one, which may mean that consumer satisfaction can be measured through a set of attributes in the destination, which corresponded to the satisfaction or not of the expectations generated by the tourist, affecting and influencing in this way the image of the destination, confirming the hypothesis 2 .

- Hypothesis 2: The more positive the image of a destination, the greater the consumer satisfaction. The correlation between the personal brand and the image was positive, although it presented moderate values, thus confirming the hypothesis 3.

- Hypothesis 3: The more positive the personal brand image, the greater the likelihood of influencing the image of Destiny. The explanation for this result may be related to the subjectivity of the brand's value in the tourist destination. Through the correlation between the variable personal brand and purchase, and the destination satisfaction variable, a lower result was obtained than the 
previous one, however positive, confirming the hypothesis 4.

- Hypothesis 4: The more positive the brand image, the more likely it is to buy the target. This fact, as in hypotheses 3 and 4, may be related to the value attributed to the personal brand, thus influencing the recommendation, though in a less significant way, which leads us to believe that before the results, personal branding may be a factor influential, but not a deciding factor in the image of a tourist destination. To conclude, the highest value was obtained through the correlation between the satisfaction variable and the recommendation variable and the destination satisfaction and revisit variable, whose correlation values are more significant and positive, confirming hypothesis 5 and 6.

- Hypothesis 5: The greater the tourist satisfaction in the destination, the greater the likelihood of destination recommendation.

- Hypothesis 6: The greater the tourist satisfaction in the destination, the greater the probability of revisiting the tourist destination. This hypothesis confirms what has already been mentioned in the literature review and argued by several authors that consumer satisfaction at a destination increases the likelihood that consumers will return to that destination, since the expectations they have created were partly satisfied, influencing in this way their behavioral attitude.

\section{RESULTS AND DISCUSSION}

The variables used to measure the sociodemographic profile of the respondents are: age, gender, educational qualifications, professional status, and monthly income of respondents. It is observed that the sample was composed of 147 respondents where $49 \%$ are female, while $51 \%$ are male. This distribution was balanced, since responses of both genders were obtained almost equally. Regarding to the group of respondents, the age group with the largest respondents was 45 to 54 and 55 to 64 years old, with $20 \%$ each one, followed by the age group 35 to 44 years old with $19 \%$, the age ranges between 25 to 34 years old with 18\%.and more than 65 years old with 17\%, and with lower values between 18 to 24 years old with 5\% of 
respondents. Regarding the nationality of the respondents, and considering that our sample was relatively small due to the short time in which it was administered, it was possible to verify a high diversity of tourists since of the 147 respondents were identified 19 different nationalities. It was also observed that the highest number of tourists in this sample is represented by German nationality $22 \%$, British nationality with $23 \%$, Spanish nationality with $8 \%$, representing the national market $15 \%$ of the respondents. The remaining respondents are distributed by different nationalities. Regarding the monthly salary of respondents $17 \%$ of the sample has an income lower than $1000 €$, and $44 \%$ of the sample have a net monthly salary between 1000 $€$ and $2500 €$. Following this analysis it was observed that $22 \%$ obtained a monthly net income between $2501 €$ and $4000 €$ and $12 \%$ of respondents more than $4000 €$ per month.

To understand the relationships between the variables in this study, we used the Pearson correlation coefficient, since we intend to correlate between interval variables, proving to be the most adequate association test (Martins, 2011). Using the IBM SPSS program we proceeded to associate the variables of the model, to determinate the level of correlation between them. Pearson correlation coefficient allows the evaluation of the strength and direction of this association, varying between +1 and -1 . $A+1$ correlation means that there is a perfect positive correlation between two variables; in contrast, a -1 correlation means that there is a perfect negative correlation (Martins, 2011). The correlations between the variables are significant from 0.01 , since they are positive. A correlation matrix was constructed between the variables of the proposed conceptual model to present the results obtained, necessary to test the hypotheses in this study. Based on Pearson's correlation coefficient and its variation, the associations between the study variables are all positive and statistically significant, varying between 0.546 ** (Destination Image and Personal Brand) and 0.700 ** (Recommendation and Satisfaction). The results obtained through the correlations made between the variables validate the premise that the personal brand influences the buying behavior of the tourist and the dimensions (study variables) that compose it, also some of these influence each other.

With the highest value, we present the association between the Satisfactory and 
Recommendation variables: $r=0.700 * * ; p<0.01$ ( $p$ corresponds to the significance value). This value reveals a strong correlation between the variables. This relationship supports the fact that the satisfaction that the customers have in the destination affect the recommendation of the same to third parties (hypothesis 5). In the correlation between the satisfaction and revisit variables, it was obtained a value of $r=0.661{ }^{*} ; p<0.01$. The correlation between the two variables is a moderate positive correlation, this value evidences and supports the idea that satisfaction influences the revisit to a tourist destination (hypothesis 6).

The correlation between the target image variable and the purchase variable obtained a value of: $r=0.587^{\star *} ; p<0.01$. The correlation between the two variables is a moderate positive correlation, where it is observed that the image variable of a destination has a moderating effect on consumer buying behavior, and based on the value obtained it can be concluded that the destination image has a moderate effect on the purchase (hypothesis1). This presents significant positive values, thus supporting the proposed association. The Personal Brand variable presents a reasonable degree of correlation with the Purchase variable, resulting in the value: $r$ $=0.419 * * ; p<0.01$. The correlation between the two variables is a weak positive correlation. This value validates the idea that the personal brand influences the consumer's purchasing decision, which is stated in the literature in the past, according to which several authors argue that brands are in the minds of consumers (hypothesis 4). The correlation between the association of the Personal branding and Destination Image variables presents a moderating value $=0.546$ ** $p<0.01$. The correlation between the two variables is a moderate positive correlation. This validates the idea that the brand image influences the image of destiny in the consumer's mind (hypothesis 3). Finally, regarding the association between the Image of Destination and Satisfaction variable, the value presented: $r=0.206$ **; $p$ $<0.01$. The idea that the image of fate influences consumer satisfaction has less force than the previous correlation, and it can be concluded that the former has a moderate effect on the second (hypothesis 2). The correlation between the two variables is a correlation with lower strength when compared to the previous variables. However, it presents significant positive values, thus supporting the proposed association. Tourism is one of the main industries at the global level, and it 
has grown the most over the years, playing an important role in the world economy and contributing positively to the development of several countries (Ferreira et al., 2018; Buhalis \& Foerste, 2015). As tourism is an activity that involves the movement of the consumers to the place of production (Buhalis \& Costa, 2006), there are several aspects that must be taken into account in the process of developing the sector.

\section{CONCLUSIONS, LIMITATIONS AND FUTURE RESEARCH}

The present research study aimed to the impact of the personal brand in a tourism context, analyzing the Madeira case. The intention was to understand how the personal brand, namely the brand of Cristiano Ronaldo (CR7), influences the image of the region, through the application of questionnaire surveys in several points of the region. Research questions were elaborated that through an empirical study, through a quantitative approach, resulted in the verification and confirmation of all the hypotheses raised. The model used in this research was based on models already used in previous investigations, and allows to add a new dimension existing model of Bigné (2001), the personal brand dimension. We have verified the hypotheses that had already been validities in previous studies, but that in terms of tourist context could not be verified.

All the correlations made in the study were confirmed and presented positive results, some of them being significant. The destination image has an influence on consumer buying behavior, however it seems to have little influence on tourist satisfaction, since the lowest results correspond to the relationship between the destination image variable and tourist satisfaction. The fact that it has a lower value, thus reveals a lower probability of influencing consumer satisfaction. This may be related to the need for the tourist to attribute more value to the experiences lived in the destination, that is, the tourist seeks to live the experiences, feel that he is part of the environment that visits, which leads us to reflect on the need of the entities responsible for the promotion of tourism and by the providers of tourist services bet on authenticity so as not to lose tourism to other destinations. The personal brand influences the target image in the same way that influences your purchase, albeit 
with lower values. The satisfaction variable has a positive and significant influence on the recommendation variable, which is reflected in the need to guarantee tourist satisfaction in the destination, since the more satisfied with the experience, the greater the likelihood of recommending it to third parties.

Satisfaction influences in a positive way the behavior of the consumer with regard to the recommendation of the destination whose relationship between the two variables presented the highest value demonstrating the strong relation between them. The more satisfied the tourist is, the greater the likelihood of recommending the destination to third parties, it is believed that it will be important to provide the tourists with good experiences in the destination, these experiences begin from the commercialization of the destination, purchase, accompaniment until their return to their origin. The satisfaction variable also revealed to be a determining factor in the consumer behavior since it also influences the revisit although with lower values, which does not mean that the tourist is not satisfied, but because it wants to know new destinations and to acquire new experiences. The central objective of this study was reached, however there were some limitations in the same. One of the limitations found in this study was the administration of the surveys, since field work was done for this purpose, but in a short period of time for different reasons. The application of questionnaires in paper format becomes a time-consuming and difficult process, coupled with the fact that many are hesitant to collaborate, which was reflected in our sample, since of the 147 validated for data treatment. Seasonality was another of the limitations encountered during the application of the surveys, although this is not felt with high intensity in the island of Madeira, since it is frequent to find tourism in this destination throughout the year. Another limitation is that we cannot generalize the collected data since our sample is a small sample.

In a future research on the subject it would be interesting to bridge the limitations felt in this study and complement it through a qualitative analysis to several entities associated with the CR7 brand in Madeira, namely the museum. In this way it would be possible to obtain data regarding the profile of tourists who see the museum, the Hotel Pestana CR7, and later the airport of Madeira in order to obtain data that allow us to identify the type of tourist and their interests. After understanding the tourist it may be possible to analyze the possible bet in certain market segments by the 
competent entities in the area of promotion of the destination, by promoting the authenticity of attributes in this destination thus contributing to the differentiation of Madeira destination. For example the bet on the type of tourism that contemplates celebrities, taking advantage of the fact that there are unique resources in this destination, whose purpose is to promote more tourism in the region, attracting to the destination new market niches. In future research, we intent to show shows how these valid questions can be answered by introducing causal modelling and discussing one approach to it, structural equation modelling (SEM), which is a rigorous technique for building and testing such models. It is an advanced statistical methodology that delivers models and results that are easy to understand and employ. We intent to confirm that a causal relationship exists (i.e. measurement over time should confirm that change in one variable precedes change in the other; a controlled experiment is required that changes a single variable; the direction of causality must be correctly specified; the relationship must not disappear when common causes of both are removed and the causal effect 'makes sense' in domain knowledge) (Elliott, 2003). It would be interesting to apply the surveys in all courses of the region, as well as carry out the study in different months, including the high season, which could allow a diversification of respondents as well as increasing the number of responses.

\section{References}

Anholt, S. Branding de locais e países. In: R. Clifton; J. Simmons (Eds). O Mundo das Marcas. Lisboa: Actual Editora, 2005.

Ashworth, G.J.; Voogd, H. Marketing and place promotion. In: J.R. Gold; S.V. Ward (Eds). Place promotion: the use of publicity and marketing to sell towns and regions. Chichester: John Wiley and Sons, 1994, pp. 39-52.

Baker, D.A.; Crompton, J.L. Quality, satisfaction and behavioral intentions. Annals of Tourism Research, Vol. 27, No 3, 2000, pp. 785-804. 
Bigne, J.E.; Andreu, L. Emotions in segmentation: An empirical study. Annals of Tourism Research, Vol. 31, No 3, 2004, pp. 682-696.

Bigne, J.E.; Sanchez, M.I.; Sanchez, J. Tourism image, evaluation variables and after purchase behaviour: inter-relationship. Tourism Management, Vol. 22, No 6, 2001, pp. 607-616.

Brems, C.; Temmerman, M.; Graham, T.; Broersma, M. Personal Branding on Twitter: How employed and freelance journalists stage themselves on social media. Digital Journalism, Vol. 5, No 4, 2017, pp. 443-459.

Brito, C. Uma abordagem relacional ao valor da marca. Revista Portuguesa e Brasileira de Gestão [online], Vol. 9, No 1-2, 2010, pp. 49-63.

Brooks, A.K.; Anumudu, C. Identity development in personal branding instruction. Adult Learning, Vol. 27, No 1, 2016, pp. 23-29.

Blain, C.; Levy, S.E.; Ritchie, J.B. Destination branding: Insights and practices from destination management organizations. Journal of Travel Research, Vol. 43, No 4, 2005, pp. 328-338.

Buhalis, D.; Costa, C. (Eds.). Tourism management dynamics: trends, management and tools. Amsterdam: Elsevier Butterworth-Heinemann, 2006.

Buhalis, D.; Foerste, M. SoCoMo marketing for travel and tourism: Empowering cocreation of value. Journal of Destination Marketing \& Management, Vol. 4, No 3, 2015, pp. 151-161.

Cronin Jr., J.J.; Brady, M.K.; Hult, G.T.M. Assessing the effects of quality, value, and customer satisfaction on consumer behavioral intentions in service environments. Journal of Retailing, Vol. 76, No 2, 2000, pp. 193-218. 
Dick, A.S.; Basu, K. Customer loyalty: toward an integrated conceptual framework. Journal of the Academy of Marketing Science, Vol. 22, No 2, 1994, pp. 99-113.

Engel, J.F.; Blackwell, R.D.; Miniard, P.W. Consumer behavior. Ohio: South Western Educational Publishing, 1993.

Elliott, M.R. Causality and how to model it. BT Technology Journal, Vol. 21, No 2, 2003, pp. 120-125.

Ferreira, J.; Sousa, B.M.; Gonçalves, F. Encouraging the subsistence artisan entrepreneurship in handicraft and creative contexts. Journal of Enterprising Communities: People and Places in the Global Economy, In press.

García de Soto Camacho, E.; Álvarez Torrescusa, M. Choice of entry mode into the internationalisation process by dominant Spanish hotel chains. Enlightening Tourism. A Pathmaking Journal, Vol. 8, No 2, 2018, pp. 128-157.

Gehl, R.W. Ladders, samurai and blue collars: Personal branding in Web 2.0. First Monday, Vol. 16, No 9, 2011, pp. 3-24.

Gertner, D.; Kotler, P. How can a place correct a negative image? Place Branding, Vol. 1, No 1, 2004, pp. 50-57.

Ghodeswar, B.M. Building brand identity in competitive markets: a conceptual model. Journal of Product \& Brand Management, Vol. 17, No 1, 2008, pp. 4-12.

Hearn, A. Meat, masks, burden: Probing the contours of the branded self. Journal of Consumer Culture, Vol. 8, No 2, 2008, pp. 197-217.

Holladay, P., Dixon, A., Nguyen, M., Nguyen, B., Xu, S., \& Price-Howard, K. Stakeholder perceptions of tourism assets and sustainable tourism development in 
Da Nanga, Vietnam. Enlightening Tourism. A Pathmaking Journal, Vol. 8, No 2, 2018, pp. 74-98.

Howard, D.R.; Crompton, J.L. Who are the consumers of public park and recreation services? An analysis of the users and non-users of three municipal leisure service organizations. Journal of Park and Recreation Administration, Vol. 2, No 3, 1984, pp. 33-48.

Hu, Y.; Ritchie, J.B. Measuring destination attractiveness: A contextual approach. Journal of Travel Research, Vol. 32, No 2, 1993, pp. 25-34.

Hwang, S.N.; Lee, C.; Chen, H.J. The relationship among tourists' involvement, place attachment and interpretation satisfaction in Taiwan's national parks. Tourism Management, Vol. 26, No 2, 2005, pp. 143-156.

Johnson, K.M. The importance of personal branding in social media: educating students to create and manage their personal brand. International Journal of Education and Social Science, Vol. 4, No 1, 2017, pp. 21-27.

Kavaratzis, M. From city marketing to city branding: Towards a theoretical framework for developing city brands. Place Branding, Vol. 1, No 1, 2004, pp. 58-73.

Kavaratzis, M.; Ashworth, G. Place marketing: how did we get here and where are we going? Journal of Place Management and Development, Vol. 1, No 2, 2008, pp. 150-165.

Keller, K.L.; Lehmann, D.R. Brands and branding: Research findings and future priorities. Marketing Science, Vol. 25, No 6, 2006, pp. 740-759.

Khedher, M. Personal branding phenomenon. International Journal of Information, Business and Management, Vol. 6, No 2, 2014, pp. 29-40. 
Khedher, M. An inspiring resource for developing personal branding phenomena. Marketing Review, Vol. 15, No 1, 2015, pp. 117-131.

Kleppinger, C.A.; Cain, J. Personal digital branding as a professional asset in the digital age. American Journal of Pharmaceutical Education, Vol. 79, No 6, article 79, 2015, pp. 1-4.

Kim, S.B.; Sun, K.A.; Kim, D.Y. The influence of consumer value-based factors on attitude-behavioral intention in social commerce: the differences between high-and low-technology experience groups. Journal of Travel \& Tourism Marketing, Vol. 30, No 1-2, 2013, pp. 108-125.

Kotler, P. Administração de Marketing: Análise, Planejamento, Implementação e Controle. São Paulo: Atlas, 1998. In: Administração de Marketing: A Edição do Novo Milênio. São Paulo: Prentice Hall, 2000.

Kotler, P.; Zaltman, G. Social marketing: an approach to planned social change. Journal of Marketing, Vol. 35, No 3, 1971, pp. 3-12.

Kotler, P.; Levy, S.J. Broadening the concept of marketing. Journal of Marketing, Vol. 33, No 1, 1969, pp. 10-15.

Kozak, M. Measuring tourist satisfaction with multiple destination attributes. Tourism Analysis, Vol. 7, No 3-4, 2003, pp. 229-240.

Labrecque, L.I.; Markos, E.; Milne, G.R. Online personal branding: Processes, challenges, and implications. Journal of Interactive Marketing, Vol. 25, No 1, 2011, pp. 37-50.

Lair, D.J.; Sullivan, K.; Cheney, G. Marketization and the recasting of the professional self. Management Communication Quarterly, Vol. 18, No 3, 2005, pp. 307-343. 
McGuire, F.A.; O'Leary, J.T. The implications of leisure constraint research for the delivery of leisure services. Journal of Park and Recreation Administration, Vol. 10, No 2, 1992, pp. 31-40.

Moilanen, T.; Rainisto, S. (2009). How to brand nations, cities and destinations. A planning book for place branding. Basingstoke: Palgrave MacMillan, 2009, pp. 65-75.

Montoya, P.; Vandehey, T. The brand called you: make your business stand out in a crowded marketplace. New York: McGraw-Hill Education, 2008.

Murphy, J.M. (Ed.). Branding: A key marketing tool. London: Macmillan, 1987.

Oliver, R.L. Measurement and evaluation of satisfaction processes in retail settings. Journal of Retailing, Vol. 57, No 3, 1981, pp. 25-48.

Ostrom, A.; lacobucci, D. (1995). Consumer trade-offs and the evaluation of services. Journal of Marketing, Vol. 95, No 1, 1995, pp. 17-28.

Otto, J.E.; Ritchie, J.B. The service experience in tourism. Tourism Management, Vol. 17, No 3, 1996, pp. 165-174.

Parasuraman, A.; Zeithaml, V.A.; Berry, L.L. A conceptual model of service quality and its implications for future research. Journal of Marketing, Vol. 49, No 4, 1985, pp. 41-50.

Peters, T. The brand called you. Fast Company, No 10, 1997, pp. 83-89.

Rein, I.; Kotler, P.; Haider, D. Marketing Places: Attracting Investment, Industry, and Tourism to Cities, States, and Nations. New York: Free Press, 1993.

Richers, R. O enigmático mais indispensável consumidor: teoria e prática. Revista de Administração da Universidade de São Paulo, Vol. 19, No 3, 1984, pp. 46-56. 
Sousa, B.; Ribeiro, I. City marketing e os eventos: um estudo sobre as perceções dos residentes face ao Carnaval de Ovar. European Journal of Applied Business Management, Special Issue, 2018, pp. 73-84.

Sousa, B.; Vasconcelos, S. Branding territorial e o papel da imagem no comportamento do consumidor em turismo: O caso de Arouca. European Journal of Applied Business Management, Special Issue, 2018, pp. 1-14.

Sousa, B.; Vieira, C. Um Estudo Sobre a Afetividade Aplicada ao Fenómeno do Futebol: Abordagem na Ótica dos Consumidores. PODIUM Sport, Leisure and Tourism Review, Vol. 7, No 2, 2018, pp. 293-312.

Sousa, B.; Simões, C. Comportamento e perfil do consumidor de turismo de nichos. Tékhne-Revista de Estudos Politécnicos, No 14, 2010, pp. 137-146.

Tasci, A.D.; Kozak, M. Destination brands vs destination images: Do we know what we mean? Journal of Vacation Marketing, Vol. 12, No 4, 2006, pp. 299-317.

Vargas-Sánchez, A.; Porras-Bueno, N.; Plaza-Mejía, M.A. Residents' attitude to tourism and seasonality. Journal of Travel Research, Vol. 53, No 5, 2014, pp. 581596.

Vargas-Sánchez, A.; Porras-Bueno, N.; Plaza-Mejía, M.A. Explaining residents' attitudes to tourism: Is a universal model possible? Annals of Tourism Research, Vol. 38, No 2, 2011, pp. 460-480.

Vargas-Sánchez, A.; Plaza-Mejia, M.A.; Porras-Bueno, N. Understanding residents' attitudes toward the development of industrial tourism in a former mining community. Journal of Travel Research, Vol. 47, No 3, 2009, pp. 373-387.

Veal, A.J. Research methods for leisure and tourism. London: Pearson, 2017. 
Veal, A.J.; Cushman, G. Leisure in different worlds: the survey evidence. In: Leisure in industrial and post-industrial societies. Eastbourne: Leisure Studies Association, 1996, pp. 401-412.

Vitberg, A.K. Analog vs. Digital personal branding-A new twist on personal marketing plans. CPA Practice Management Forum, No 5, 2009, pp. 10-13.

Zarkada, A. Concepts and Constructs for Personal Branding: An Exploratory Literature Review Approach [online]. 2012. Retrieved from: https://ssrn.com/abstract=1994522 [accessed 10 January 2019].

Article info: Received 10/01/2019. Accepted 11/03/2019. Refereed anonymously. 